\title{
Kedisiplinan Terhadap Prestasi Belajar Siswa Kelas VIII SMPN 1 Woha
}

\author{
Samsudin \\ STKIP Taman Siswa Bima \\ samsudinspdmor@gmail.com
}

\begin{abstract}
Abstrak. Tujuan penelitian ini untuk mengetahui kedisiplinan terhadap prestasi belajar pada siswa kelas VIII SMP Negeri 1 Woha. Penelitian ini merupakan penelitian deskriptif. Populasi dalam penelitian ini seluruh siswa kelas VIII SMP Negeri 1 Woha yang berjumlah 180 orang siswa terdiri dari 7 kelas, dengan jumlah sampel 27 orang siswa. Teknik pengumpulan data dalam penelitian ini menggunakan angket, dokumentasi, dan observasi. Teknik anailisa data dalam penelitian ini menggunakan analisa statistik dengan rumus Korelasi Product Moment. Kesimpulan dalam peneltian ini ada pengaruh latihan target terhadap kemampuan shooting dalam permainan sepakbola pada siswa putra kelasX Al Maliki. Kesimpulan dalam penelitian ini ada Kedisiplinan terhadap prestasi belajar pada siswa kelas VIII SMP Negeri 1 Woha
\end{abstract}

\section{Kata Kunci: Kedisiplinan, Prestasi Belajar} PENDAHULUAN

Pendidikan nasional berfungsi mengembangkan kemampuan dan membentuk watak serta peradaban bangsa yang bermartabat dalam rangka mencerdaskan kehidupan bangsa, bertujuan untuk berkembangnya potensi peserta didik agar menjadi manusia yang beriman dan bertakwa kepada Tuhan Yang Maha Esa, berakhlak mulia, sehat, berilmu, cakap, kreatif, mandiri, dan menjadi warga negara yang demokratis serta bertanggung jawab (UU Sisdiknas No. 20 Tahun 2003).

Sadar akan hakikatnya, setiap manusia Indonesia di muka bumi ini selalu berbuat untuk hal yang lebih baik. Untuk mengubah prilaku menuju ke hal yang lebih baik itu tidaklah mudah yang kita bayangkan. Perubahan itu melalui perjalanan yang panjang, berjenjang, dan berkesinambungan. Satu-satunya jalur yang dapat ditempuh yakni dengan pendidikan.

Siswa merupakan orang yang terlibat langsung dalam dunia pendidikan. Dalam perkembangannya harus melalui proses belajar. Termasuk di dalamnya belajar mengenal diri, belajar mengenal orang lain, dan belajar mengenal lingkungan sekitarnya. Ini dilakukan agar siswa dapat mengetahui dan menempatkan posisinya di tengah-tengah masyarakat sekaligus mampu mengendalikan diri.
Sifat pengendalian diri harus ditumbuh kembangkan pada diri siswa. Pengendalian diri di sini dimaksudkan adalah suatu kondisi dimana seseorang dalam perbuatannya selalu dapat menguasai diri sehingga tetap mengontrol dirinya dari berbagai keinginan yang terlalu berlebihan. Berarti dalam sifat pengendalian diri tersebut terkandung keteraturan hidup dan kepatuhan akan segala peraturan. Dengan kata lain, perbuatan siswa selalu berada dalam koridor disiplin dan tata tertib sekolah. Bila hal ini terjadi, maka akan tumbuh rasa kedisiplinan siswa untuk selalu mengikuti tiap-tiap peraturan yang berlaku di sekolah karena menaati peraturan tersebut merupakan suatu kewajiban bagi setiap siswa.

Masalah kedisiplinan siswa menjadi sangat berarti bagi kemajuan sekolah (Nursisto, 2002:78). Di sekolah yang tertib akan selalu menciptakan proses pembelajaran yang baik. Sebaliknya, pada sekolah yang tidak tertib kondisinya akan jauh berbeda. Pelanggaran-pelanggaran yang terjadi sudah dianggap barang biasa dan untuk memperbaiki keadaan yang demikian tidaklah mudah. Hal ini diperlukan kerja keras dari berbagai pihak untuk mengubahnya, sehingga berbagai jenis pelanggaran terhadap disiplin dan tata tertib sekolah tersebut perlu dicegah dan ditangkal. 
Tingkat kedisiplinan siswa pada akhir-akhir ini umumnya masih tergolong memprihatinkan. Kuantitas pelanggaran yang dilakukan oleh siswa semakin bertambah dari waktu ke waktu. Dari berbagai jenis pelanggaran tata tertib sekolah, misalnya banyaknya siswa yang bolos atau minggat pada waktu jam belajar, perkelahian, terlambat datang ke sekolah, malas belajar, sering tidak masuk sekolah, tidak mengerjakan tugastugas yang diberikan guru, tidak membuat pekerjaan rumah, merokok, dan lain-lain. Secara garis besar banyaknya pelanggaran yang dilakukan oleh siswa akan berpengaruh terhadap kemajuan dan prestasi belajar di sekolah.

Menurut salah satu guru di SMP Negeri 1 Woha dari hasil wawancara Peneliti pada tangga 14 Oktober 2011 bahwa siswa yang selalu tertib akan selalu menciptakan proses pembelajaran yang baik sehingga prestasi belajarnya meningkat yang dibuktikan dengan hasil nilai rapor siswa. Sebaliknya, pada siswa yang tidak tertib akan jauh berbeda sehingga prestasi belajar siswa menurun. Oleh karena itu, keisiplina siswa bertujuan untuk mendidik siswa agar sanggup memerintahkan diri sendiri. Mereka dilatih untuk dapat menguasai kemampuan, juga melatih siswa agar ia dapat mengatur dirinya sendiri, sehingga para siswa dapat mengerti kelemahan atau kekurangan yang ada pada dirinya sendiri.

Berdasarkan latar belakang di atas, maka penulis merasa tertarik untuk melakukan riset atau penelitian dengan judul "Pengaruh Kedisiplinan Terhadap Prestasi belajar Siswa Kelas VIII SMP Negeri 1 Woha.

Prestasi belajar adalah kalimat yang terdiri dari dua kata yakni "prestasi dan belajar" antara kata "prestasi dan belajar" mempunyai arti yang berbeda. Prestasi adalah hasil dari suatu kegiatan yang telah dikerjakan, diciptakan, baik secara individual maupun kelompok (Djamarah, 2004: 19).

Sedangkan menurut Slameto (2002:13), "Belajar adalah suatu proses usaha yang dilakukan individu untuk memperoleh suatu perubahan tingkah laku yang baru secara keseluruhan, sebagai hasil pengalaman individu itu sendiri dalam interaksi dengan lingkungannya".

Untuk memperoleh hasil belajar tersebut secara umum dapat dipengaruhi oleh dua faktor yaitu faktor intern dan ekstern. Hal ini dijelaskan dalam pendapat berikut: "hasil yang dicapai oleh siswa dipengaruhi oleh dua faktor utama dalam diri siswa dan faktor yang datang dari luar diri siswa atau faktor lingkungan. Faktor yang datang dari dalam diri siswa terutama kemampuan yang dimilikinya. Di samping faktor kemampuan yang dimiliki siswa juga ada faktor lain seperti motivasi belajar, minat dan perhatian, sikap dan kebiasaan belajar, ketekunan, sosial, ekonomi, faktor fisik dan psikis" (Sudjana, 2002: 23).

Setelah menelusuri uraian di atas maka dapat dipahami mengenai makna kata "prestasi dan belajar". Prestasi pada dasarnya hasil yang dicapai oleh seseorang setelah melakukan kegiatan belajar yang berupa pengetahuan, keterampilan serta sikap dan tingkah laku untuk mengatasi atau memecahkan kesulitan yang dihadapi.

Kalau perubahan tingkah laku adalah tujuan yang akan dicapai dari aktifitas belajar, maka perubahan tingkah laku itulah salah satu indikator yang dijadikan pedoman untuk kemajuan yang diperoleh itu tidak saja berupa ilmu pengetahuan tapi juga berupa kecakapan atau keterampilan. Semuanya bisa diperoleh di bidang suatu mata pelajaran tertentu. Kemudian untuk mengetahui penguasaan setiap siswa terhadap mata pelajaran tertentu itu dilaksanakanlah evaluasi. Dan evaluasi itulah akan dapat diketahui kemajuan siswa.

Uraian singkat ini peneliti dapat merumuskan definisi prestasi belajar sebagai berikut yaitu "prestasi belajar adalah hasil usaha atau kegiatan yang telah dicapai dalam perubahan tingkah laku yang sebelumnya belum pernah diperoleh individu setelah melakukan kegiatan belajar. Jadi pada intinya bahwa orang yang belajar, tidak sama benar keadaannya dengan sebelum mereka melakukan perbuatan belajar.

Prestasi belajar memiliki fungsi dan tujuan tertentu. Fungsi dan tujuan prestasi belajar dapat dijelaskan menurut pendapat Sudjana (2002: 3-5) sebagai berikut: a) Fungsi prestasi belajar, untuk 
Jurnal Ilmu Sosial dan Pendidikan

http://ejournal.mandalanursa.org/index.php/JISIP/index

Terakreditasi Peringkat 5 (No. SK: 85/M/KPT/2020)

mengetahui seberapa besar tercapainya pembelajaran, untuk dijadikan rujukan perbaikan program pembelajaran, untuk dijadikan landasan pelaporan tentang kemajuan siswa kepada orang tuanya, b) Tujuan prestasi belajar, untuk menggambarkan kecakapan siswa pada mata pelajaran tertentu, untuk menggambarkan keberhasilan sekolah dalam proses pendidikan dan pengajaran, untuk dijadikan dasar tingkat kecakapan atau kemampuan siswa, baik untuk melanjutkan pelajaran ke jenjang pendidikan selanjutnya atau untuk terjun ke dunia kerja.

Adapun faktor yang mempengaruhi prestasi belajar secara umum adalah faktor internal dan eksternal ; a) Faktor Internal. Faktor internal yakni faktor yang ada dalam diri individu yang belajar. Faktor ini dapat dibagi menjadi dua. yaitu "faktor jasmaniah dan faktor rohaniah" (Slameto, 2005: 54), b) Faktor jasmaniah. Proses belajar seseorang akan terganggu jika kesehatannya terganggu, selain itu juga akan cepat mengalami kelelahan, kurang bersemangat. mudah pusing jika badan lemah atau ada gangguan dan kelainan fungsi alat indra (Slameto, 2005: 54).

Untuk menciptakan belajar yang baik harus mengusahakan kesehatan tetap terpelihara. Dalam hal ini nutrisi harus cukup, karena kekurangan kadar makanan akan menyebabkan kurangnya kondisi jasmani yang pengaruhnya dapat berupa kelesuan dan sebagainya yang dapat memberikan pengaruh terhadap kegiatan belajar dan hasil belajar; 1) Psikologis (Rohani). Banyak faktor fsikologis yang dapat mempengaruhi prestasi belajar siswa. Namun diantara faktor-faktor rohani yang dipandang esensial itu adalah tingkat kecerdasan, perhatian, bakat, minat dan motivasi siswa, (a) Tingkat kecerdasan. Dalam kaitannya dengan tingkat kecerdasan seorang ahli menyatakan bahwa tingkat kecerdasan atau intelegensi adalah suatu kecakapan yang terdiri dari tiga jenis yaitu kecakapan untuk menghadapi dan menyesuaikan kedalam situasi yang baru dengan cepat dan efektif, mengetahui atau menggunakan konsep-konsep yang abstrak secara efektif dan mengetahui hubungan dan mempelajarinya dengan cepat (Slameto, 2005 :
Vol. 4. No. 4 November 2020

p-ISSN: 2598-9944 e- ISSN: 2656-6753

56). (b) Perhatian. Disamping tingkat kecerdasan faktor rohani yang ikut berpengaruh adalah perhatian. Untuk dapat menjamin hasil belajar yang baik siswa harus mempunyai perhatian terhadap materi yang dipelajarinya, apabila bahan pelajaran tidak menjadi perhatian siswa, maka yang akan timbul kebosanan, kejenuhan, sehingga siswa tidak suka belajar. (c) Bakat siswa. Bakat adalah kemampuan untuk belajar. Kemampuan itu baru dapat terrealisasi menjadi kecakapan yang nyata apabila sesudah belajar itu berlatih (Slameto, 2005 :57), (d) Minat siswa. Slameto (2005:57) menjelaskan bahwa minat adalah kecenderungan yang tetap untuk memperhatikan dan mengemas beberapa kegiatan. Apabila kegiatan atau pekerjaaan itu diminati oleh siswa maka akan diperhatikannya secara terus-menerus dan disertai dengan rasa senang, (e) Motivasi. Yang mendorong seseorang atau siswa untuk berbuat sesuatu ialah motivasi baik itu motivasi dari dalam dirinya (Intrinsik) atau yang berasal di luar dirinya (ekstrinsik) (Muhibbin, 2004 : 136). Motivasi instrinsik yang berasal dari dalam diri siswa sendiri yang dapat mendorong untuk melakukan tindakan belajar, termasuk menyenangi materi tersebut. misalnya untuk kehidupan masa depan siswa. Sedangkan motivasi ekstrinsik yaitu keadaan yang datang dari luar individu juga mendorongnya untuk melakukan kegiatan belajar misalnya pujian. hadiah dan guru, (f) Faktor Eksternal. Faktor eksternal adalah faktor yang datang dari luar diri siswa yang belajar. Adapun faktor eksternal yang dimaksud adalah faktor lingkungan. Lingkungan adalah sesuatu yang berada di sekitar kita yang ada hubungannva dan berpengaruh terhadap perkembangan manusia (Rusyan, 2003:148). Lingkungan yang berpengaruh terhadap prestasi belajar siswa dapat digolongkan menjadi dua jenis yaitu lingkungan sosial dan non sosial. 2) Lingkungan Sosial. Salah seorang ahli menjelaskan bahwa lingkungan sosial yaitu lingkungan masyarakat dimana dalam lingkungan tersebut adanya interaksi individu yang satu dengan individu yang lain. Maksudnya masyarakat yang merupakan teman bergaul seperti anggota keluarga (termasuk orang tua), dan teman 
Jurnal Ilmu Sosial dan Pendidikan

http://ejournal.mandalanursa.org/index.php/JISIP/index

Terakreditasi Peringkat 5 (No. SK: 85/M/KPT/2020)

sepergaulan turut mempengaruhi individu dalam belajarnya.

Adapun lingkungan sosial tersebut dapat digolongkan menjadi lingkungan keluarga, sekolah dan masyarakat. (a) Lingkungan keluarga. Lingkungan keluarga disini adalah orang tua. Dalam kegiatan belajar seorang anak perlu diberikan dorongan dan pengertian oleh orang tua. Adapun hal-hal yang berpengaruh terhadap siswa dalam lingkungan keluarga adalah suasana di dalam rumah, relasi antara anggota keluarga dan ekonomi keluarga, (b) Lingkungan sekolah. Lingkungan sekolah merupakan lembaga formal yang memiliki program-program yang direncanakan berdasarkan peraturan-peraturan yang telah ditetapkan. Di sekolah, anak dihadapkan dengan orang-orang baru (guru dan teman-teman di kelas), dengan tugas-tugas yang berbeda dengan tugas di rumah, pola dan tingkah laku yang berlainan dengan di rumah. Adapun halhal yang memberi pengaruh terhadap siswa dilingkungan sekolah adalah interaksi guru dengan murid, relasi antar sesama siswa, metode mengajar guru, disiplin sekolah dan keadaan gedung. Semua faktor yang ada di lingkungan sekolah di atas dapat memberikan pengaruh terhadap kegiatan belajar dan prestasi belajar siswa, (Lingkungan masyarakat. Masyarakat adalah sekumpulan orang yang menempati suatu daerah diikat oleh pengalaman yang sama, oleh hukum atau peraturan-peraturan, memiliki pemimpin, sadar akan kesatuannya, dan dapat bertindak bersama untuk mencukupi krisis kehidupannya" (Barnadib, 2002: 133). Pengaruh lingkungan di atas bisa datang dari teman-teman sebaya, anak-anak tetangga, orang-orang dewasa dan perluasan pergaulannya, sehingga semakin banyak pula faktor-faktor yang mempengaruhinya seperti media massa, teman bergaul, kegiatan di masyarakat, bentuk kehidupan masyarakat atau cara hidup lingkungan. 3) Lingkungan non social. Di samping faktor sosial di atas, faktor non sosial pun juga berpengaruh dalam membentuk pribadi anak, termasuk dalam kegiatan belajarnya. Suasana lingkungan eksternal yang menyangkut cuaca, waktu, kondisi tempat, penerangan, dan
Vol. 4. No. 4 November 2020

p-ISSN: 2598-9944 e- ISSN: 2656-6753

sebagainya, mempengaruhi sikap dan reaksi individu dalam aktivitas belajarnya sebab individu yang belajar adalah interaksi dengan lingkungannya.

Dari ketiga ulasan di atas dapat dipahami bahwa antara individu yang belajar dengan lingkungannya saling mempengaruhi dalam usahanya memperoleh hasil belajar (prestasi) yang baik. Lingkungan alam yang berbeda memberikan pengaruh yang berbeda pula terhadap individu. Oleh karena itu bahwa antara individu yang belajar dengan lingkungan berperan dalam belajarnya. Dalam hal ini upaya penyesuaian diri sangat perlu dilakukan, karena anak tidak bisa lepas dari interaksi dengan lingkungannya termasuk lingkungan alam.

Dari uraian di atas, jelaslah bahwa dalam proses belajar mengajar terdapat dua faktor yang dapat mempengaruhinya yaitu faktor internal dan eksternal, salah satu faktor yang dapat mempengaruhi prestasi belajar siswa dalam penelitian ini adalah lingkungan sekolah. Dengan demikian, dapat disimpulkan bahwa salah satu faktor ekstenal yang dapat mempengaruhi prestasi belajar siswa dalam lingkungan sekolah adalah kegiatan ekstra kurikuler.

Dalam kehidupan sehari-hari kita tidak lepas dari aktivitas atau kegiatan, kadang kegiatan itu kita lakukan dengan tepat waktu tapi kadang juga tidak. Kegiatan yang kita laksanakan secara tepat waktu dan dilaksanakan secara kontinyu, maka akan menimbulkan suatu kebiasaan. Kebiasaan dalam melaksanakan kegiatan secara teratur dan tepat waktulah yang biasanya disebut disiplin dalam kehidupan sehari-hari. Disiplin diperlukan di manapun, karena dengan disiplin akan tercipta kehidupan yang teratur dan tertata. Untuk lebih memahami tentang disiplin, berikut akan diuraikan pengertian disiplin dari beberapa ahli ; a) Menurut Lembaga Ketahanan Nasional Indonesia (Lemhanas) (2005:12) disiplin adalah kepatuhan untuk menghormati dan melaksanakan suatu sistem yang mengharuskan orang tunduk kepada keputusan, perintah atau peraturan yang berlaku, b) menurut Prijodarminto dalam Tu'u (2004:31) disiplin adalah suatu kondisi yang tercipta dan 
Jurnal Ilmu Sosial dan Pendidikan

http://ejournal.mandalanursa.org/index.php/JISIP/index

Terakreditasi Peringkat 5 (No. SK: 85/M/KPT/2020)

berbentuk melalui proses dari serangkaian perilaku yang menunjukan nilai-nilai ketaatan, kepatuhan, kesetiaan, keteraturan dan keterikatan, c) menurut Maman Rachman (2007:23) menyatakan disiplin sebagai upaya mengendalikan diri dan sikap mental individu atau masyarakat dalam mengembangkan kepatuhan dan ketaatan terhadap peraturan dan tata tertib berdasarkan dorongan dan kesadaran yang muncul dari dalam hatinya, d) Muhibin (2004;34) membedakan kata disiplin dengan mendisiplin. Disiplin biasanya diartikan sebagai perilaku dan tata tertib yang sesuai dengan peraturan dan ketetapan, atau perilaku yang diperoleh dari pelatihan, seperti disiplin dalam kelas atau disiplin dalam tim bola basket yang baik. Sedangkan kata mendisiplin didefinisikan sebagai menciptakan keadaan tertib dan patuh dengan pelatihan dan pengawasan dan menghukum atau mengenakan denda, membetulkan, menghukum demi kebiasaan.

Disiplin dan belajar di atas maka yang dimaksud disiplin belajar dalam penelitian ini adalah sikap atau tingkahlaku siswa yang taat dan patuh untuk dapat menjalankan kewajibannya untuk belajar, baik belajar di sekolah maupun belajar di rumah. Indikator disiplin belajar dalam penelitian ini adalah: ketaatan terhadap tata tertib sekolah, ketaatan terhadap kegiatan belajar di sekolah, ketaatan dalam mengerjakan tugas-tugas pelajaran, dan ketaatan terhadap kegiatan belajar di rumah.

Seorang siswa harus disiplin dalam menaati tata tertib sekolah, disiplin dalam belajar di sekolah, disiplin dalam mengerjakan tugas, maupun disiplin dalam belajar di rumah, sehingga akan dicapai hasil belajar yang optimal. Disiplin berperan penting dalam membentuk individu yang berciri keunggulam. Menurut Tu'u (2004:37) disiplin penting karena alasan berikut ini ; a) dengan disiplin yang muncul karena kesadaran diri, siswa berhasil dalam belajarnya. Sebaliknya siswa yang kerap kali melanggar ketentuan sekolah pada umumnya terhambat optimalisasi potensi dan prestasinya, b) tanpa disiplin yang baik, suasana sekolah dan juga kelas menjadi kurang kondusif bagi kegiatan pembelajaran.
Vol. 4. No. 4 November 2020

p-ISSN: 2598-9944 e- ISSN: 2656-6753
Secara positif disiplin memberi dukungan yang tenang dan tertib bagi proses pembelajaran, c) orang tua senantiasa berharap di sekolah anakanak dibiasakan dengan norma norma, nilai kehidupan, dan disiplin. Dengan demikian anakanak dapat menjadi individu yang tertib, teratur, dan disiplin, d) disiplin merupakan jalan bagi siswa untuk sukses dalam belajar dan kelak ketika bekerja.

Kesadaran pentingnya norma, aturan, kepatuhan, dan ketaatan merupakan prasarat kesuksesan seseorang Sedangkan menurut Maman Rachman (2007:35) pentingnya disiplin bagi para siswa adalah sebagai berikut; a) memberi dukungan bagi terciptanya perilaku yang tidak menyimpang, b) membantu siswa memahami dan menyesuaikan diri dengan tuntutan lingkungan, c) cara menyelesaikan tuntutan yang ingin ditunjukan peserta didik terhadap lingkunganya, d) untuk mengatur keseimbangan keinginan individu satu dengan individu lainnya, e) menjauhi siswa melakukan hal-hal yang dilarang sekolah, f) mendorong siswa melakukan hal-hal yang baik dan benar, g) peserta didik belajar hidup dengan kebiasaan-kebiasaan yang baik, positif dan bermanfaat baginya dan lingkungannya, h) kebiasaan baik itu menyebabkan ketenangan jiwanya dan lingkungannya

Dari uraian di atas dapat disimpulkan bahwa disiplin sangat penting dan dibutuhkan oleh setiap siswa. Disiplin yang tumbuh secara sadar akan membentuk sikap, perilaku, dan tata kehidupan yang teratur yang akan menjadikan siswa sukses dalam belajar.

Fungsi disiplin sangat penting untuk ditanamkan pada siswa, sehingga siswa menjadi sadar bahwa dengan disiplin akan tercapai hasil belajar yang optimal. Fungsi disiplin menurut Tu'u (2004:38-44) adalahsebagai berikut: a) Menata kehidupan bersama. Manusia merupakan mahluk sosial. Manusia tidak akan bisa hidup tanpa batuan orang lain. Dalam kehidupan bermasyarakat sering terjadi pertikaian antara sesama orang yang disebabkan karena benturan kepentingan, karena manusia selain sebagai mahluk sosial ia juga sebagai mahluk individu 
Jurnal Ilmu Sosial dan Pendidikan

http://ejournal.mandalanursa.org/index.php/JISIP/index

Terakreditasi Peringkat 5 (No. SK: 85/M/KPT/2020)

yang tidak lepas dari sifat egonya, sehingga kadang-kadang di masyarakat terjadi benturan antara kepentingan pribadi dengan kepentingan bersama. Di sinilah pentingnya disiplin untuk mengatur tata kehidupan manusia dalam kelompok tertentu atau dalam masyarakat. Sehingga kehidupan bermasyarakat akan tentram dan teratur, b) Membangun kepribadian. Kepribadian adalah keseluruhan sifat, tingkah laku yang khas yang dimiliki oleh seseorang. Antara orang yang satu dengan orang yang lain mempunyai kepribadian yang berbeda. Lingkungan yang berdisiplin baik sangat berpengaruh terhadap kepribadian seseorang. Apalagi seorang siswa yang sedang tumbuh kepribadiannya, tentu lingkungan sekolah yang tertib, teratur, tenang, dan tentram sangat berperan dalam membangun kepribadian yang baik, c) Melatih kepribadian yang baik. Kepribadian yang baik selain perlu dibangun sejak dini, juga perlu dilatih karena kepribadian yang baik tidak muncul dengan sendirinya. Kepribadian yang baik perlu dilatih dan dibiasakan, sikap perilaku dan pola kehidupan dan disiplin tidak terbentuk dalam waktu yang singkat, namun melalui suatu proses yang membutuhkan waktu lama, d) Pemaksaan. Disiplin akan tercipta dengan kesadaran seseorang untuk mematuhi semua ketentuan, peraturan, dan noma yang berlaku dalam menjalankan tugas dan tanggung jawab. Disiplin dengan motif kesadaran diri lebih baik dan kuat. Dangan melakukan kepatuhan dan ketaatan atas kesadaran diri bermanfaat bagi kebaikan dan kemajuan diri. Sebaliknya disiplin dapat pula terjadi karena adanya pemaksaan dan tekanan dari luar. Misalnya, ketika seorang siswa yang kurang disiplin masuk ke satu sekolah yang berdisiplin baik, maka ia terpaksa harus menaati dan mematuhi tata tertib yang ada di sekolah tersebut, f) Hukuman. Dalam suatu sekolah tentunya ada aturan atau tata tertib. Tata tertib ini berisi hal-hal yang positif dan harus dilakukan oleh siswa. Sisi lainnya berisi sanksi atau hukuman bagi yang melanggar tata tertib tersebut. Hukuman berperan sangat penting karena dapat memberi motivasi dan kekuatan bagi siswa untuk mematuhi tata tertib
Vol. 4. No. 4 November 2020

p-ISSN: 2598-9944 e- ISSN: 2656-6753 dan peraturan-peraturan yang ada, karena tanpa adanya hukuman sangat diragukan siswa akan mematuhi paraturan yang sudah ditentukan, h) Menciptakan lingkungan yang kondusif. Disiplin di sekolah berfungsi mendukung terlaksananya proses kegiatan pendidikan berjalan lancar. Hal itu dicapai dengan merancang peraturan sekolah, yakni peraturan bagi guru-guru dan bagi para siswa, serta peraturan lain yang dianggap perlu. Kemudian diimplementasikan secara konsisten dan konsekuen, dengan demikian diharapkan sekolah akan menjadi lingkungan pendidikan yang aman, tenang, tentram, dan teratur.

Perilaku disiplin tidak akan tumbuh dengan sendirinya, melainkan perlu kesadaran diri, latihan, kebiasaan, dan juga adanya hukuman. Bagi siswa disiplin belajar juga tidak akan tercipta apabila siswa tidak mempunyai kesadaran diri. Siswa akan disiplin dalam belajar apabila siswa sadar akan pentingnya belajar dalam kehidupannya. Penanaman disiplin perlu dimulai sedini mungkin mulai dari dalam lingkungan keluarga. Mulai dari kebiasaan bangun pagi, makan, tidur, dan mandi harus dilakukan secara tepat waktu sehingga anak akan terbiasa melakukan kegiatan itu secara kontinyu. Menurut Tu'u (2004:48-49) mengatakan ada empat faktor dominan yang mempengaruhi dan membentuk disiplin yaitu: a) Kesadaran diri. Sebagai pemahaman diri bahwa disiplin penting bagi kebaikan dan keberhasilan dirinya. Selain itu kesadaran diri menjadi motif sangat kuat bagi terwujudnya disiplin. Disiplin yang terbentuk atas kesadarn diri akan kuat pengaruhnya dan akan lebih tahan lama dibandingkan dengan disiplin yang terbentuk karena unsur paksaan atau hukuman, b) Pengikutan dan ketaatan. Sebagai langkah penerapan dan praktik atas peraturanperaturan yang mengatur perilaku individunya. Hal ini sebagai kelanjutan dari adanya kesadaran diri yang dihasilkan oleh kemampuan dan kemauan diri yang kuat, c) Alat pendidikan. Untuk mempengaruhi, mengubah, membina, dan membentuk perilaku yang sesuai dengan nilainilai yang ditentukan atau diajarkan, d) Hukuman. Seseorang yang taat pada aturan cenderung 
Jurnal Ilmu Sosial dan Pendidikan

http://ejournal.mandalanursa.org/index.php/JISIP/index

Terakreditasi Peringkat 5 (No. SK: 85/M/KPT/2020)

disebabkan karena dua hal, yang pertama karena adanya kesadaran diri, kemudian yang kedua karena adanya hukuman. Hukuman akan menyadarkan, mengoreksi, dan meluruskan yang salah, sehingga orang kembali pada perilaku yang sesuai dengan harapan.

\section{METODE PENELITIAN}

Penelitian ini merupakan penelitian deskriptif yang bertujuan untuk menyajikan gambaran lengkap mengenai setting sosial atau dimaksudkan untuk eksplorasi dan klarifikasi mengenai suatu fenomena atau kenyataan sosial, dengan jalan mendeskripsikan sejumlah variabel yang berkenaan dengan masalah dan unit yang diteliti antara fenomena yang diuji.

Populasi dalam penelitian ini seluruh siswa kelas VIII SMP Negeri 1 Woha yang berjumlah 180 orang siswa terdiri dari 7 kelas, dengan jumlah sampel 27 orang siswa.

Teknik pengumpulan data dalam penelitian ini yaitu, menggunakan angket, dokumentasi, dan observasi. Pilihan angket sebagai alat pengumpul data penelitian diiringi oleh suatu asumsi bahwa data penelitian akan mudah diraih dengan mengajukan dalam bentuk tertulis. Peneliti membuat sedemikian rupa pertanyaan dalam item soal dan jawabannya telah ditentukan oleh peneliti sendiri berupa Cek List $(\sqrt{ })$. Adapun kisi-kisi angket dalam penelitian ini dapat diuraikan dalam tabel berikut :

Tabel 1. Kisi-kisi Angket Kedisiplinan

\begin{tabular}{|ll|}
\hline \multicolumn{1}{|c|}{ Pertanyaan Positif } \\
\hline 1. & Mertanyaanai seragam sekolah \\
2. & Memakai kelengkapan seragam sekolah \\
3. & Datang sekolah tepat waktu \\
4. & Masuk kelas tepat waktu \\
5. & Mengerjakan tugas dari guru tepat waktu \\
6. Mengikuti upacara bendera \\
7. Memberi keterangan saat tidak hadir \\
8. Meminta izin saat meninggalkan sekolah \\
9. Meminta izin saat meninggalkan mata \\
10. Melajaran \\
11. Mawabanakan tugas piket dengan tanggung \\
\hline
\end{tabular}

Vol. 4. No. 4 November 2020 p-ISSN: 2598-9944 e- ISSN: 2656-6753
12. Terlibat dalam kegiatan jum'at bersih

13. Membayar SPP tepat waktu

14. Membayar sumbagan lainya tepat waktu

15. Berbicara sopan dengan warga sekolah lainya

Pertanyaan Negatif

1. Datang sekolah tidak tepat waktu

2. Tidak hadir tanpa keterangan

3. Meningggalkan sekolah tanpa izin

4. Tidak mengikuti upacara bendera

5. Tidak hadir kegiatan ekstrakurikuler

6. Tidak hadir kegiatan pramuka

7. Tidak mengerjakan tugas dari guru

8. Tidak mengikuti kegiatan keagamaan

9. Menyalahgunakan iuran sekolah

10. Bersikap tidak sopan

11. Terlibat perkelahian

12. Minumman keras dan narkoba

13. Menghisap rokok di sekolah

14. Terlibat pencurian di sekolah

Membuang sampah sembarangan

Penerapan dokumentasi dalam penelitian ini dimaksudkan untuk memperoleh data tentang prestasi belajar yaitu rata-rata ulangan harian siswa pada mata pelajaran olahraga siswa kelas VIII SMP Negeri 1 Woha.

Observasi yang digunakan adalah observasi obyektif yang hanya mengamati kondisi nyata dari subyek atau perilaku yang dilihat. Pada intinya observasi hanya melakukan pengamatan dengan mengandalkan penglihatan semata. Data yang ingin diperoleh dengan menggunakan metode observasi antara lain: gambaran umum lokasi penelitian dan aktivitas guru dan siswa dalam kegiatan belajar mengajar.

Teknik anailisa data dalam penelitian ini menggunakan analisa statistik dengan rumus Korelasi Product Moment. Adapun persamaan rumus tersebut, sebagai berikut :

$$
r=\frac{\sum x y}{\sqrt{\left(\sum x^{2}\right)\left(\sum y^{2}\right)}}
$$

Sumber : (Suharsimi Arikunto, $2010: 217$ ) Keterangan :

$\mathrm{R}$ : Koefisien korelasi antar variabel $\mathrm{x}$ dan $\mathrm{y}$

$\mathrm{X}$ : Kedisiplinan 
Jurnal Ilmu Sosial dan Pendidikan

http://ejournal.mandalanursa.org/index.php/JISIP/index

Terakreditasi Peringkat 5 (No. SK: 85/M/KPT/2020)

\section{HASIL DAN PEMBAHASAN}

Hasil penelitian analisis data menunjukkan nilai $\mathrm{rxy}=0,991$ untuk responden sebanyak 27 orang, dengan $r$ tabel $=0,381$ pada traf signikan $5 \%$. Ini menunjukkan bahwa Ha diterima dan Ho ditolak, berarti ada pengaruh kedisiplinan terhadap prestasi belajar pada siswa kelas VIII SMP Negeri 1 Woha, dan hal ini menunjukkan bahwa kedisiplinan di sekolah sangat berpegaruh terhadap preses belajar mengajar di sekolah khusunya di SMPN 1 Woha Kabupaten Bima. Sikap disiplin sangat penting dan dibutuhkan oleh setiap siswa yang tumbuh secara sadar akan membentuk sikap, perilaku, dan tata kehidupan yang teratur yang akan menjadikan siswa sukses dalam belajar.

Sejalan dengan penelitian yang dilakukan oleh Rosdiana (2005) dalam skripsinya yang berjudul "Pengaruh Kedisiplinan terhadap peningkatan prestasi olahraga pada siswa SMP Negeri 2 Bonjeruk Lombok Tengah tahun ajaran 2005/2006. yang bertujuan untuk mengetahui pengaruh kedisiplinan terhadap peningkatan prestasi belajar pada siswa SMP 2 Bonjeruk lombok tengah tahun pelajaran 2005/2006. Hipotesis yang diajukan adalah ada pengaruh metode kedisiplinan terhadap peningkatan prestasi olahraga pada siswa, dengan menggunakan analisis statistik dengan rumus koofesien korelasi produk moment, dan hasil penelitian menunjukan ada pengaruh kedisiplinan terhadap peningkatan prestasi olahraga pada siswa SMP 2 Bonjeruk, hal ini sesuai dengan analisis data dimana $\mathrm{r}_{\text {hitung }}$ lebih besar yaitu 0,447 dari pada $r_{\text {tabel }}$ yaitu 0,254. Artinya apabila kedisiplinan yang diterapkan oleh guru di sekolah berjalan sesuai dengan yang direncanakan maka prestasi olahraga siswa akan meningkat.

Hal ini sejalan dengan pendapat Tu'u, disiplin penting karena berbagai alasan yaitu ; a). dengan disiplin yang muncul karena kesadaran diri, siswa berhasil dalam belajarnya. Sebaliknya siswa yang kerap kali melanggar ketentuan sekolah pada umumnya terhambat optimalisasi

Vol. 4. No. 4 November 2020

p-ISSN: 2598-9944 e- ISSN: 2656-6753

potensi dan prestasinya, b). tanpa disiplin yang baik, suasana sekolah dan juga kelas menjadi kurang kondusif bagi kegiatan pembelajaran. Secara positif disiplin memberi dukungan yang tenang dan tertib bagi proses pembelajaran, c). orang tua senantiasa berharap di sekolah anakanak dibiasakan dengan norma norma, nilai kehidupan, dan disiplin. Dengan demikian anakanak dapat menjadi individu yang tertib, teratur, dan disiplin, d). disiplin merupakan jalan bagi siswa untuk sukses dalam belajar dan kelak ketika bekerja.

\section{KESIMPULAN}

Kesimpulan dalam penelitian ini ada Kedisiplinan terhadap prestasi belajar pada siswa kelas VIII SMP Negeri 1 Woha.

\section{DAFTAR PUSTAKA}

Arikunto Suharsimi. (2010). Prosedur Pendekatan Praktek (suatu pedekatan praktis), PT Rineka Cipta Jakarta.

Djamarah. (2001). Strategi Belajar Mengajar, Jakarta : Rineka Cipta

Maman Rahaman. (2007). Pendidikan Kewarga Negaraan Untuk SMP/MTs, Semarang : Bengawan Ilmu

Muhibin. (2004). Psikologi Pendidikan, Bandung : Remaja Rosda Karya

Musa Ahmad. (2005). Perana Sekolah Terhadap Kedisiplinan Siswa di SMP Negeri 15 Mataram.

Rusyan. (2003). Faktor-faktor dalam prestasi Belajar, Jakarta : Bina Aksara

Slameto. (2005). Belajar dan Faktor-faktor Yang Mempengaruhinya, Jakarta : Bina Aksara Sudjana. (2010). Metode Penelitian Dalam Pendidikan, Bandung : Alfabet

Tu'u. (2004). Kedisiplinan dan Faktor Yang Mempengaruhinya, Bandung : Angkas

Undang -Undang Sisdiknas No. 20 Tahun 2003 Bab. II Pasal 3 